\title{
O MEMORIAL CONSTITUCIONAL E A QUESTÃO INDÍGENA NO BRASIL THE MEMORIAL CONSTITUTIONAL AND INDIGENOUS ISSUES IN BRAZIL
}

Guilherme Camargo Massaú* Gabriel Bandeira Coelho***

Resumo: Após um século de constitucionalismo, o Estado brasileiro, a partir da Constituição Federal de 1988, reconhece a importância da cultura indígena, estabelecendo em capítulo específico os direitos e as garantias próprias dos povos indígenas. Constata-se, historicamente, o "esquecimento" ou desprezo do "civilizador" em relação a esses povos, que somente em 1988 obtiveram o reconhecimento constitucional à dignidade dos descendentes dos primeiros habitantes do território brasileiro. Com isso, o objetivo do artigo consistiu em destacar que, embora a Constituição de 1988 tenha dado um salto considerável no tratamento do tema, o Estado, pressionado por interesses econômicos e políticos, continua incorrendo em atos que violam as normas da Constituição no que se refere aos povos indígenas. Para a obtenção da conclusão, utilizou-se o método expositivo, com a finalidade de expor a estrutura teórico-constitucional, e o descritivo, para indicar os fatos sociais que indicam a violação que tem ocorrido no que concerne aos direitos dos povos indígenas. Posteriormente, cotejou-se a teoria constitucional com a dos fatos correntes e foram constatadas violações de normas constitucionais após o reconhecimento da dignidade indígena, em 1988. Nesse sentido, o problema, atualmente, não está no reconhecimento dos direitos dos povos indígenas, mas, sobretudo, em fazê-los realidades sociais. Também se conclui que tais violações são impulsionadas pelo interesse econômico, principalmente pela cobiça das terras povoadas pelos diversos povos indígenas.

Palavras-chave: Constituição Federal de 1988. Direitos Fundamentais. Índio. Memória. Violações.
Abstract: After a century of constitutionalism, the Brazilian State, from the Federal Constitution of 1988, recognizes the importance of indigenous culture, establishing in a specific chapter the guarantees and rights of indigenous peoples. It appears, historically, "forgetting" or contempt of the "civilizing" in relation to these people, who until 1988 had the constitutional recognition of the dignity of the descendants of the first inhabitants of the Brazilian territory. Thus, the aim of this article was to emphasize that, although the 1988 Constitution has given a considerable leap in the treatment of the subject, the State, pressured by economic and political interests remains fallen into acts that violate the norms of the Constitution as refers to indigenous peoples. To reach the conclusion used the lecture method, in order to expose the theoretical and constitutional structure, and descriptive, to indicate the social facts that indicate the violation (today) occurred related to the rights of indigenous peoples. Once collated the constitutional theory with current facts and were found violations of constitutional norms, after the recognition of indigenous dignity in 1988. The problem nowdays is not in recognizing the rights of indigenous peoples, but to make them social realities. Also it is concluded that such violations are driven by economic interests, mainly populated by the greed of the land by many indigenous peoples.

Keywords: Federal Constitution of 1988. Fundamental Rights. Indian. Memory. Violations.

\footnotetext{
* Doutor em Direito Público pela Universidade do Vale do Rio dos Sinos (Unisinos), RS; Mestre em Ciências Jurídico-Filosóficas pela Universidade de Coimbra, Portugal; Professor da Faculdade de Direito e do Mestrado em Sociologia da Universidade Federal de Pelotas (UFPel), RS; Capão do Leão, 96160-000, Rio Grande do Sul, Brasil; uassam@gmail.com

** Mestre em Sociologia e Graduado em Ciências Sociais e pela Universidade Federal de Pelotas (UFPel), RS; Professor do Instituto Federal Sul-Rio-Grandense (IFSul), RS; Rua General Osório, 932, Centro, 96020-000, Pelotas, Rio Grande do Sul, Brasil; gabrielbandeiracoelho@yahoo.com.br
} 


\section{Introdução}

O trabalho parte do pressuposto de que cada norma carrega, em si, uma memória, uma história. Os motivos para a sua existência se encontram no reconhecimento alcançado pela aquisição de uma consciência histórica. Trata-se de uma arquitetura planejada para cumprir uma função de proteção, de manutenção e de desenvolvimento de um objetivo. Embora a Constituição de 1891 traga algumas normas que dizem respeito aos povos indígenas, estas estão preocupadas em agregar o índio à "civilização" nacional e em resguardar as suas terras, ou seja, descaracterizá-los. Somente com a Constituição de 1988 se reconheceu a importância e a necessidade de reservar regulamentação própria para o povo indígena.

Depois de um século de constitucionalismo, contando com a Constituição Imperial (1821), o Estado brasileiro estabelece a importância, não apenas histórica, mas cultural, do Índio, ao reservar o Capítulo VIII do Título VIII. Como são normas hierarquicamente superiores, na disposição normativa os povos indígenas passam a estar na posse de tratamento e reconhecimento devido, pelo menos, normativamente. Infere-se, historicamente, o "esquecimento" ou desprezo do "civilizador" em relação a esses povos, mas também se constata, em 1988, a retomada da "memória" no que se refere ao reconhecimento à dignidade dos descendentes dos primeiros habitantes do território brasileiro.

A "desmemorização" não é própria do campo jurídico-constitucional, mas de todo um contexto histórico de formação e de desenvolvimento do Estado-Nação. É consequência do processo educacional civilizador do colonizador que foi absorvido, fortemente, pelas sucessivas gerações "civilizadoras". Observa-se isso no desenrolar das narrativas históricas impressas nas pesquisas e na importância atribuída pelos pesquisadores ao tema indígena.

O Índio e a sua cultura ainda são pouco pesquisados nas áreas do Direito e da Sociologia, por exemplo. Porém, tal cenário vem sofrendo alterações. A causa indígena encontra-se em ascensão, justamente pelo reconhecimento de sua importância para delimitar e definir a identidade e a história do povo brasileiro. Isso é consequência do reconhecimento constitucional e da dignificação que esse reconhecimento exige.

Contudo, alguns eventos demonstram alguns lapsos de "memória" do Estado e da sociedade brasileira ao colocarem em risco determinados povos e culturas indígenas, violando as normas constitucionais condizentes com os direitos indígenas. Embora a Constituição de 1988 tenha dado um salto considerável no tratamento do tema, o Estado, pressionado por interesses econômicos, continua "desmemorizado" e desdenhoso em relação ao Título VIII e ao Capítulo VIII da Constituição. Para chegar a essa conclusão, utilizou-se o método expositivo, com a finalidade de expor a estrutura teórico-constitucional. Posteriormente, empregou-se o método descritivo, destacando, dessa forma, os fatos sociais que indicam a violação (ainda hoje) dos direitos dos povos indígenas. Por conseguinte, o trabalho possui quatro 
etapas anteriores à conclusão. A primeira consiste no situar histórico-constitucional, a segunda aponta para as normais da Constituição atual, a terceira enfatiza pontos centrais da perspectiva histórica e atual do índio no Brasil, e por fim, a última salienta elementos que demonstram as violações constitucionais no que diz respeito aos direitos dos indígenas ocorridas e divulgadas pela imprensa brasileira, sublinhando, nesse sentido, que a Constituição de 1988, mesmo na atualidade, não possui plena efetividade no que se refere aos povos indígenas - especialmente seu direito à terra.

\section{A história e a Constituição como memória}

O fenômeno jurídico é caracterizado pela sua constituenda historicidade, o que possibilita investigá-lo e tratá-lo como Direito no decorrer do tempo. Entre o passado e o presente é possível denominar Direito diversas manifestações normativas em inúmeros locais. Com isso, admitem-se as diferentes formas de compreensão jurídica. A multiplicidade de visões incidentes sobre o fenômeno jurídico não indica arbitrariedade; pelo contrário, apenas mostra as variações de visões de mundo sob um mesmo fenômeno, nada além da admissão de diversas experiências histórico-objetivas de quem está lançado (aí) no mundo. Para que se possa admitir uma concepção jurídica, é necessário partir do entendimento de Direito à época. Para que determinada concepção seja admitida como jurídica, é imperial que se tenha o fundamento a priori (metafísico ou não, dependendo como o Direito é visualizado) vigente. Admitir um fundamento não é aceitá-lo passivamente como o mais adequado, mas partir de um ponto dominante, para afirmá-lo ou contrariá-lo no presente e estruturar ações para o futuro.

Então, inferem-se a condicionalidade do entendimento e a coerência humanas à própria experiência. Assim, por mais plural que sejam as opiniões, visões teórico-práticas, há um ponto e um limite comum. Os que ignoram essas delimitações perdem o contato com o próprio mundo-da-vida. Tanto para a corrente da História que admite a descrição dos fatos pelo historiador quanto para a outra corrente que admite a construção de um passado pelo historiador (HESPANHA, 1971, p. 8), ambas precisam iniciar em um ponto comum originado pelo amálgama de fatores e valores do passado. Tal ponto é o momento da memória; é o conteúdo fornecido pela História, que se torna dominante - a História oficial (nem sempre corresponde aos fatos passados realmente). A memória pode ser afirmada ou contestada, mas para isso é preciso partir da própria memória. Em princípio, a memória é a História oficial; os pontos comuns em que os coexistentes de mesmo mundo tomam o conhecimento do passado podem compreender o presente e planejar o futuro. Isso implica considerar o ser humano como um ser histórico.

Esse ser histórico produz e modifica seu próprio mundo, o da cultura. Estando o Direito inserido nesse mundo, concebido pelas mãos humanas, este constitui-se em um produto cultural, o qual consiste na prática de proferir juízos valorativos sobre as situações da vida social, representados, nos Estados modernos, pela legislação 
(HESPANHA, 1971, p. 46). Por conseguinte, independe-se do tipo de interpretação (literal, teleológica, sistemática) para determinar o significado do texto, pois este sempre estará inserido na cápsula da história com suas intenções normativas. O Direito não se reduz à lei; concentra-se nas intenções normativas de ideais axiológico-jurídicos que, em um momento histórico, o intérprete, por meio da hermenêutica, recolhe-as da legislação para poder realizá-las (HESPANHA, 1971, p. 48).

A ordem jurídica não é produto do acaso, do arbítrio infundado ou do decreto do legislador; sobre esta reside a sua historicidade constituenda e a do operador jurídico. Uma regra pode ter diversos significados em relação aos princípios, em determinado tempo e espaço; porém, em outra condição, é possível que possua um significado distinto. A compreensão da norma variará de acordo com a memória empregada pelo intérprete; se for a oficial, terá um sentido; se for a não oficial, ${ }^{1}$ terá outro diferente. Como o intérprete carrega a sua memória, a lei possui a sua própria. Nesse sentido, poderá ocorrer a fusão de horizontes ${ }^{2}$ de memórias, memória oficial com oficial ou memória oficial com não oficial. Nessa última fusão, encontra-se o descompasso entre as intenções normativas da lei com a situação de fato social analisada, impossibilitando o encaixe das intenções normativas com o fato social e o estabelecimento de conflito entre essas duas ordens.

\subsection{A Constituição e a história: a memória}

A ideia de Constituição traz consigo a possibilidade de unir um estado de coisas distinto do anterior com uma ordem político-jurídica. Assim sucedera em $1776 \mathrm{com}$ as colônias que formaram os Estados Unidos da América, em relação à Pátria mãe; como em 1789, com a queda do antigo regime na França, e em 1791, com a revolução constitucional, que substituiu o sistema monárquico. A Constituição, nesses exemplos, trouxe expectativas de mudança para um futuro de liberdade e democracia, pois, sem uma Constituição, não é possível se alcançar qualquer grau de liberdade; isso aplica-se à Declaração do Homem e do Cidadão francesa de 1789. Uma ordem constitucional carrega em si uma carga de memória que envolve diversos direitos e deveres, como a liberdade, a igualdade, a democracia, a divisão de poderes, os direitos fundamentais, entre outros (VORLÄNDER, 2009, p. 7 e 9). A Constituição, em última instância, no aspecto histórico, objetiva evitar um retroceder histórico-político das instituições do Estado.

A ordem constitucional projeta uma nova concepção capacitada a ser conservada contra situações adversas e a permanecer durante a passagem do tempo,

\footnotetext{
1 A memória não oficial contradiz ou se distingue da oficial, mas, como a oficial, também advém da seleção de fatos históricos.

2 A compreensão não está limitada pela ideia originária do autor, nem pela concepção do destinatário original do texto. A compreensão é sempre interpretação, pois se trata do horizonte hermenêutico que fornece a validade para o texto. Destarte, todos os intérpretes são filhos de seu tempo, possuem conceitos prévios e preconceitos, típicos de seu tempo (GADAMER, 2008, p. 511 e 513).
} 
em decorrência de sua prevalência normativa com suas expectativas manifestas. No mesmo sentido de Thomas Paine, a Constituição deve ser considerada a Bíblia do Estado; os membros do Governo e do povo deveriam possuir a sua, pois esta atribui à política uma ordem institucional. $\mathrm{O}$ caráter sacral refere-se à sua superioridade às demais normas e não ultrapassa a incidência do tempo e das mudanças sociais; o seu texto sofre a mutação na sua compreensão. A sua índole é constituir uma ordem política de modo fundamentante a decidir litígios e problemas da vida político-social (VORLÄNDER, 2009, p. 9).

É na Constituição que se encontram os direitos fundamentais, as atribuições de competência aos órgãos superiores e à organização do Estado. A Magna Carta abriga os preceitos essenciais do poder, tanto do Estado quanto dos cidadãos, ao fixar os objetivos, as finalidades e os princípios a vigorarem na sociedade; para as constituições modernas, esses princípios são diretamente compreensivos. ${ }^{3}$ Isso implica separar a validade dos Direito Humanos, do Estado de direito e do Estado social em relação ao poder político, ao ponto de este poder não interferir arbitrariamente nos princípios e normas concernentes aos fundamentos do Estado; ou seja, são normas intangíveis ao poder constituinte derivado. Nisso, encontra-se uma das características da Constituição moderna exsurgida com os documentos estadunidense e francês no século XVIII. Também se caracteriza por ser escrita, conter um catálogo de direitos fundamentais e por estabelecer a organização da separação dos poderes. Certamente, a diferença marcante da Constituição moderna para a antiga está na soberania do povo exercida direta ou indiretamente, atribuindo, assim, à Constituição o caráter de humana, espacial e temporal (VORLÄNDER, 2009, p. 10-12).

Entre a antiga e a moderna, estão séries de fatos históricos formadores de uma experiência que impele as mudanças para uma nova forma (VORLÄNDER, 2009, p. 16). A moderna Constituição não pode repetir as marcas (consideradas) deletérias da época anterior, pois as condições sócio-humanas modificaram e, com elas, os valores. A experiência histórica constituiu uma carga de memória compositora dos documentos constitucionais modernos. Tais documentos não dispensam a divisão tripartida de poderes, a forma escrita, o elenco de direitos fundamentais, a democracia, a liberdade e a igualdade de todos os cidadãos perante o Estado. São normas que carregam na memória um passado que não se deseja repetir ou melhorar. Estas buscam, ainda, construir um futuro distinto em comparação a esse passado, regulando o presente, impulsionado pela índole normativo-constitutiva das normas constitucionais.

A memória manifesta-se expressa ou implicitamente e negativa ou positivamente nos textos fundamentais. A qualidade de "expressa" pode ser vislumbrada quando uma norma estabelece expressamente um valor ou fato, por exemplo: a proteção da ordem constitucional e o Estado Democrático do Art. $5^{\circ}$, XLIV da

\footnotetext{
${ }_{3}$ Assim, vide: Arts.: $1^{\circ}, 2^{\circ}, 3^{\circ}, 4^{\circ}$ e $5^{\circ}$ da Constituição Federal de 1988.
} 
Constituição Federal (CF) de 1988. ${ }^{4}$ O caráter "implícito" encontra-se de maneira disfarçada, inclusive pondo em dúvidas o objetivo da norma em relação ao fim a ser alcançado, por exemplo: o instituto da medida provisória (Art. $62, \S \S 2^{\circ}$ até 12 da CF). ${ }^{5}$ Os aspectos "positivo" e "negativo" dizem respeito à manutenção do passado ou sua refutação por meio de um mecanismo normativo. Poder-se-ia qualificar de positiva a memória constitucional no que diz respeito, por exemplo, aos valores e aos fatos que se enquadram no Art. $5^{\circ}$ da $\mathrm{CF}$; já o aspecto negativo pode ser visualizado no Art. 223 da $\mathrm{CF}^{6}$ - tal avaliação é claramente subjetiva, tendo os fatos históricos como elementos objetivos.

As Constituições são símbolos de uma época carregada de experiências passadas; porém, elas não são imutáveis. Pelo contrário, a partir do momento de sua disfuncionalidade com os valores dominantes, a Constituição poderá ser substituí$\mathrm{da}^{7}$ por outra, desde que o poder soberano seja emanado pelo povo (VORLÄNDER, 2009 , p. 16-20). Somente este possui a soberania e pode fixar os valores preponderantes para uma nova ordem; isso indica impor a sua memória, ${ }^{8}$ que será gravada no texto axiológico-normativo da Constituição. Esse fenômeno ocorreu no caminhar do aperfeiçoamento constitucional. As diversas Constituições contiveram as características de evitar um retorno ao passado repudiado e de garantir condições "melhores" para o futuro. A Inglaterra observou isso com a Magna Carta, a Petition of Rights e a Declaration of Rights (VORLÄNDER, 2009, p. 34-39); já os Estados Unidos, colônia da Inglaterra, absorveram as experiências inglesas e construíram a sua Constituição (VORLÄNDER, 2009, p. 39-53). Da mesma forma, os franceses compuseram a sua Constituição de 1791, ao se rebelarem contra o Ancien Regime (VORLÄNDER, 2009, p. 53-56). Cada povo agrega a sua experiência histórica e a dos outros (quando observada) para formar a sua Constituição. Cada Magna Carta possui valores preponderantes que podem ser ou não distintos das demais Constituições de outros povos ou constituições passadas do próprio Estado.

Se a Constituição carrega uma memória, o intérprete também é portador de memória (constituída ao longo da sua vida), mas esta pode ser tanto a oficial quanto a não oficial. Ao interpretar a Constituição, ocorrerá a fusão de horizontes; dessa fusão resultará uma perspectiva ímpar em face do caso em voga. A singularidade da perspectiva pode estar ou não total ou parcialmente com a memória constitucional.

\footnotetext{
4 Art. $5^{\circ}$, XLIV: "Constitui crime inafiançável e imprescritível a ação de grupos armados, civis ou militares, contra a ordem constitucional e o Estado Democrático. " (BRASIL, 1988). Contrapõe ao passado de autoritarismo vivenciado pelo Brasil.

5 Todos os parágrafos foram objetos da Emenda Constitucional n. 32, de 11 de setembro de 2001.

6 Art. 223: "Compete ao Poder Executivo outorgar e renovar concessão, permissão e autorização para o serviço de radiodifusão sonora e de sons e imagens, observado o princípio da complementaridade dos sistemas privado, público e estatal." (Brasil, 1988, p. 159). Fica a questão: qual o motivo de não remeter diretamente ao Congresso Nacional o tema da radiodifusão?

7 Neste texto, não importa quais são as formas de substituição de uma Constituição.

8 A memória imposta é considerada a oficial. Nem sempre (ou quase nunca) essa memória expressa a realidade histórica do povo; pelo contrário, mostra, na maioria das vezes, a anuência expressa ou tácita do povo diante do texto elaborado e aprovado pela Assembleia Constituinte.
} 
Se estiver de acordo total ou em parte, será constitucionalmente legítima no que está de acordo com a Carta. Se a interpretação não estiver de acordo com a Carta, esta será inconstitucional.

Ao incidir o pluralismo no contexto memorial, descobre-se ou evidencia-se com mais força uma memória não oficial, oriunda do gueto da história, escondida nos meandros da memória dominante. Não se quer aqui subverter a memória oficial ao ponto de deslocá-la ao posto de não oficial; contudo, pretende-se, apenas, trazer a memória não oficial à superfície para que esta seja confrontada com a oficial, constituindo uma comunicação dialógica. Não se deseja perverter a Constituição e sua função; pelo contrário, a partir da Constituição ter-se-á a recuperação das condições de dignidade dos portadores da memória não oficial, justamente pela abertura proporcionada pela Constituição. Para tanto, é preciso estabelecer um ponto legitimante da pluralidade a incidir na Constituição no momento da sua interpretação: a dignidade humana.

O aspecto plural tem origem nas diferenças e não na igualdade (identidade). Porém, somente quem pode produzir diferenças são os diferentes seres humanos em sua irrepetível e histórica característica. Em relação à memória, poder-se-ia criar uma espécie de parâmetro; portanto, são (mais) semelhantes os que possuem memórias parecidas e são mais díspares os que possuem memórias distintas. É possível encontrar visões de mundo completamente distintas em sociedades plurais que permitem a livre formação e a manutenção de cada memória. Em sociedades fechadas e totalitárias, a similitude prepondera, pois o cultivo da diferença memorial pode provocar grande risco à sociedade. ${ }^{9}$ Depara-se com a questão da democracia e da liberdade em relação à igualdade (identidade) ao relacioná-las às condições reais de exercer a democracia; mais identidade significa, na esteira de Hegel, a abolição das condições propícias para a democracia (KRIELE, 1990, p. 229).

\subsection{Constituição do pluralismo: o acolher da diferença memorial}

Uma sociedade plural exige uma Constituição plural, capaz de possibilitar mais diferenças sem comprometer a própria índole do Direito. Isso não significa a conivência com qualquer situação, mas a Constituição de uma premissa pluralista capaz de compreender uma variedade de ideias e de interesses na coletividade política, visualizada no local e no tempo (HÄBERLE, 1980, p. 55). As diferenças devem conviver em ordem e não violar a concepção de Direito. Uma diversidade de memórias é abarcada pela "tolerância" da expressão Constitucional, envolvendo maior abertura da própria Constituição, teorias, interpretações e intérpretes. A abertura baseia-se em direção ao futuro e ao passado; os textos clássicos, inclusive, são textos constitucionais que contribuem para a compreensão da teoria do pluralismo cons-

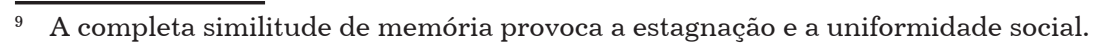


titucional. Essa teoria não pode abdicar de interpretação e política constitucional, sobretudo da fundamentação antropológica (HÄBERLE, 1980, p. 55).

A experiência como crítica normativa se refere à história - e à sua memória constitucional- como valor preponderante, por um lado; por outro, como comparação constitucional. Cada povo, cada geração, precisa constituir e encontrar a sua própria experiência, a fim de arquitetar boas instituições constitucionais. Com certeza, não é somente a Constituição que pode garantir a sucessão de gerações; é necessário que cada pessoa contribua com a continuidade dos institutos no espaço coletivo. A inserção da experiência na teoria do pluralismo constitucional é um complemento para a atualidade e a orientação do futuro da Constituição. Cabe destacar que tal pluralismo procura seu rumo entre as perspectivas conservadora e reformadora (HÄBERLE, 1980, p. 56). Então, sob a experiência, encontram-se as diversas memórias (as oficiais e as não oficiais) coexistentes.

Para alcançar o equilíbrio dessas memórias, o espectro do pluralismo deve atingir quatro domínios distintos: o sentido amplo do domínio político público; o domínio cultural, científico e artístico; o econômico; e, o domínio estatal, em sentido estreito. A Constituição surge como o pluralismo da lei (HÄBERLE, 1980, p. 56). Isso implica adotar uma teoria constitucional pluralista, uma interpretação constitucional pluralista e uma política constitucional pluralista. Tal pluralismo é formado e mantido por condições irrenunciáveis de consenso, por elementos como a dignidade humana, a informação, a opinião, a Ciência; inclusive a liberdade partidária e a oposição, além de um Estado democrático, público, social e cultural, com a separação entre os poderes e a independência jurisdicional. Esses elementos favorecem a garantia de participação dos diversos grupos sociais na construção de um ambiente comum (HÄBERLE, 1980, p. 57).

Esse modelo constitucional preocupa-se em proteger a minoria e em deixar de servir determinados grupos ou classes de cidadãos, instituindo uma tolerância interna do Homem em relação ao cidadão. É justamente essa proteção que capacita a minoria a participar plenamente do ambiente democrático e a exercer a sua cidadania (TOURAINE, 1996, p. 63-64). A manutenção do espaço público constitucional é efetuada pelo desenvolvimento do consenso guiado pelas garantias exigidas pelo próprio pluralismo constitucional que deve manter a tolerância sempre ativa. Consiste em assegurar a cada pessoa ou grupo a possibilidade de manifestação, intervenção e oposição, com suas próprias concepções (memórias) no ambiente público, dentro dos limites legais (HÄBERLE, 1980, p. 59). É, também, garantir que a pessoa ou o grupo tenha o reconhecimento de sua história, cultura, economia e política perante os demais. Nesse caso, a memória (oficial ou não) contribui para estabelecer o fundamento do reconhecimento.

As decisões que ignoram essa memória, em razão da simpatia à letra da lei, violam a pluralidade Constitucional e seus elementos anteriormente indicados. O pluralismo constitucional não pode ser apenas formal; deve ser material, incontornavelmente. Essa materialidade envolve levar a sério a memória da pessoa ou grupo, 
independentemente de qualquer circunstância, não apenas como sinal de tolerância, mas de legitimação do apelo do outro como pessoa, por causa de o pluralismo ser a medida do Homem (HÄBERLE, 1980, p. 62). O sujeito não pode ser reduzido à simples razão, pelo fato de este participar na formação, na manutenção e na alteração de identidades coletivas, em um constante movimento de inclusão e libertação, em uma luta para assumir o seu lugar de interesse (TOURAINE, 1996, p. 174).

O Homem, portanto, possui três dimensões simultaneamente implicadas: a razão, a liberdade e a memória. Essas três perspectivas podem ser traduzidas de forma prático-social ao pô-las em correspondência com a democracia. Somente esse regime político permite aflorá-las em suas respectivas potencialidades. A identidade coletiva remete à organização política, a fim de representar os interesses dos diferentes grupos sociais (memória); a razão transporta a cidadania - em uma forte marca da Revolução Francesa; e a liberdade impõe uma visão individualista que limita o poder do Estado, com o objetivo de preservar os direitos fundamentais (TOURAINE, 1996, p. 174).

\section{0 índio e as Constituições anteriores a 1988}

Cabe situar os textos constitucionais brasileiros antes de 1988, a fim de construir a imagem histórico-memorial da memória oficial constitucional. ${ }^{10}$ Ter-se-á, assim, uma noção de como o índio foi tratado durante a vigência das Constituições brasileiras. Constituir-se-á uma medida, plausível, da importância constitucional reservada aos povos que habitavam o território antes da colonização portuguesa, hodiernamente reconhecido como território brasileiro. A Constituição "Política do Império do Brasil" (1924) não reconhece nem menciona em específico os índios como povos de características culturalmente distintas das dos demais cidadãos brasileiros (ANTUNES, 2013, p. 1359). ${ }^{11}$

A Constituição da República dos Estados Unidos do Brasil, de 1891, também não faz qualquer distinção e menção aos povos indígenas (BRASIL, 1891). A Constituição da República dos Estados Unidos do Brasil, de 1934, menciona os povos indígenas (silvícolas), no sentido de trazê-los à comunidade nacional (Art. 50, XIX, “m”). O Art. 129 da Constituição de 1934 trata da posse das terras indígenas, que deverão permanecer na posse dos que ali já se encontram, de forma inalienável (BRASIL, 1934). É fonte de reconhecimento, provocando a proteção das terras tradicionalmente ocupadas pelos índios (BULOS, 2009, p. 1445). Tais dispositivos incorporam o seu reconhecimento, embora de forma insuficiente. O primeiro artigo deixa em aberto se a intenção é "civilizá-los", descaracterizando-os na autonomia cultural, ou se é para tratá-los como brasileiros, o que efetivamente já seriam. Contudo, é preciso observar

\footnotetext{
10 Salienta-se que a análise será feita de forma objetiva, ou seja, estabelecendo a existência e a localização de normas constitucionais que mencionem expressamente os povos indígenas.

11 Brasil (1924).
} 
a legislação da época para determinar qual foi a política constitucional adotada. ${ }^{12}$ No segundo dispositivo, fica evidente a intenção de preservar os povos indígenas em suas respectivas áreas, tornando-as inalienáveis e mantendo-os no local habitado, (ANTUNES, 2013, p. 1360).

A Constituição dos Estados Unidos do Brasil, de 1937, no capítulo da "Ordem Econômica", no Art. 154 (BRASIL, 1937), traz a mesma normatização do Art. 129 da Constituição de 1934. Por estar no tópico da "Ordem Econômica", atribuem-se a conotação e a valoração meramente econômicas às terras indígenas, ou seja, a manutenção dos índios em seus locais e a inalienabilidade de tais espaços. A Constituição dos Estados Unidos do Brasil de 1946 repete a Constituição de 1934 nos dois dispositivos, no Art. 5', XV, "r" (Art. 5 ${ }^{\circ}$ XIX, "m" (1934)) e Art. 216 (BRASIL, 1946) (Art. 129 (1934)) (ANTUNES, 2013, p. 1360).

A Constituição da República Federativa do Brasil, de 1967, inicialmente determina que as terras ocupadas pelos índios são bens da União (Art. $4^{\circ}$, IV). Trata-se de um dispositivo que se encontra no Capítulo I do Título I. No Capítulo II do mesmo título, o Art. $8^{\circ}$, XVII, “o”, atribui à União a competência para legislar sobre a incorporação dos índios à sociedade brasileira - repetindo o dispositivo de constituições anteriores. No Título V (Das Disposições Gerais e Transitórias), o Art. 186 (BRASIL, 1967) repete, também, o dispositivo de constituições anteriores no que diz respeito às terras ocupadas. O destacável é que tal dispositivo se localiza no final do Texto Constitucional, no sentido de corroborar apenas a questão do território indígena, mas não propriamente demonstrando uma preocupação com qualquer questão cultural indígena. A Emenda Constitucional n. 1, de 1969, que alterou substancialmente a Constituição de 1967, não traz novidade em relação aos índios, com a exceção de dois parágrafos no Art. 198 (BRASIL, 1969), basicamente a repetição do Art. 186 da Constituição de 1967. Tais parágrafos apenas ressalvam a posse dos índios nas terras habitadas por eles (ANTUNES, 2013, p. 1360-1361).

Pode-se observar que as Constituições até aqui apresentadas procuravam integrar o índio à cultura do branco. Não respeitavam, mantinham as diferenças, mas pretendiam extingui-las. Nesse sentido, os povos indígenas eram tratados de forma mais precária do que o estrangeiro. Afinal, este não tinha seus direitos fundamentais garantidos; já os indígenas, para tal, precisavam ser "civilizados", ou seja, incorporados à civilização (ANTUNES, 2013, p. 1361-1362). Até então, a memória oficial era a "civilização" do índio; as resistências encontram-se nas batalhas do cotidiano para manter a própria cultura e terras. A memória da importância do índio é retomada, pelo menos, em termos constitucionais, em 1988.

Com a Constituição da República Federativa do Brasil de 1988, depois de um século de constitucionalidade, a questão indígena ganha outra relevância, ou seja, passa a ter um grau maior de importância para o ordenamento constitucional

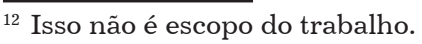


brasileiro. A palavra silvícola, inclusive, deixa de ser empregada no Texto. Segundo Bulos (2009, p. 1445), esta pode ser denominada a "Constituição do índio", justamente pela preocupação de seus legisladores com esse tema, inspirada nas Constituições da Colômbia e do Paraguai. Isso refletiu a ampla aprovação na Assembleia Nacional Constituinte, com 497 votos e foi resultado de acordos políticos envolvendo partidos políticos e segmentos sociais. Porém, não tem sido suficiente para eliminar os graves problemas que ainda afligem questões indígenas (ANTUNES, 2013, p. 1359).

A Constituição Federal preceitua no Art. 20, XI, que as terras ocupadas pelos índios são bens da União. Elas estão afetadas constitucionalmente para realizar objetivos voltados à proteção dos índios. O Art. 22, XIV, estabelece a competência privativa da União em legislar sobre as populações indígenas. O Art. 49, XVI, estabelece a competência exclusiva do Congresso Nacional para autorizar a exploração e o aproveitamento dos recursos hídricos e minerais. Acrescenta-se o Art. 176, $\S 1^{\circ}$, que estabelece requisitos para os que realizarão as pesquisas e lavras de recursos minerais ou aproveitamento de potenciais referentes ao Caput. O Art. 109, XI, fixa a competência jurisdicional em relação às disputas sobre direitos indígenas. Nesse caso, a Justiça Federal passa a ser o segmento jurisdicional competente. O Art. 129 atribui ao Ministério Público a defesa dos direitos e interesses dos índios em âmbito judicial (BRASIL, 1988 apud BULOS, 2009, p. 1454-1455).

A Magna Carta contempla, também, a educação a partir do ensino das línguas maternas e pela garantia da execução dos próprios métodos de aprendizagem nas escolas pertencentes às comunidades indígenas (Art. 210, § $2^{\circ}$ ). O Art. 215, § $1^{\circ}$, traz o compromisso do Estado na proteção das manifestações culturais indígenas. É notório que a CF de 1988 considerou os povos e as culturas que formaram a atual nação brasileira: índios, africanos, portugueses, etc. O processo civilizatório nacional foi reconhecido com a proteção da manifestação das culturas populares (BULOS, 2009, p. 1408).

Ressalta-se que os dispositivos expostos até esse momento são a demonstração da correção de uma ausência em relação ao tratamento jurídico-constitucional conferido à população indígena (BRASIL, 1988). Contudo, a Constituição Federal de 1988 foi mais longe e reservou o Capítulo VIII (Dos Índios), reconhecendo definitivamente a sua importância histórica, principalmente como povos autônomos em relação à cultura colonizadora, dignos de proteção e conservação cultural.

Os Arts. 231 e 232 da CF compõem o Capítulo VIII. No Caput do Art. 231 há o reconhecimento da organização social, costumes, línguas, crenças e tradições indígenas. São destacados os direitos originários sobre as terras, devendo a União demarcá-las e protegê-las. Os $\S \S 1^{013}$ e $2^{\circ}$ tratam sobre as terras no que se refere à utilização em face da cultura, aos costumes, aos usos e às tradições; o $\S 2^{\circ}$ repete a

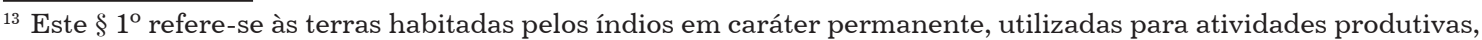
necessárias para a preservação dos recursos naturais imprescindíveis ao bem-estar e àquelas que servem à reprodução cultural e física conforme os usos, costumes e tradições (BULOS, 2009, p. 1446).
} 
norma de Constituições anteriores sobre a posse das terras tradicionalmente ocupadas. ${ }^{14}$ No Art. 67, o legislador constituinte determina um prazo de cinco anos para a União concluir a demarcação das terras indígenas (que, 25 anos depois, ainda foi concluída) (ANTUNES, 2013, p. 1371 e 1378-1379). O $\S 3^{\circ}$ do Art. 231 inclui a consulta às comunidades acerca do aproveitamento dos recursos das terras, dependendo da autorização do Congresso Nacional. ${ }^{15} \mathrm{O} \S 4^{\circ}$ determina a inalienabilidade, a indisponibilidade e a imprescritibilidade dos direitos sobre elas. O $\S 5^{\circ}$ veda a remoção das comunidades indígenas de suas terras, com a ressalva de um ad referendum do Congresso Nacional e pelos seguintes motivos: catástrofe, epidemia e interesse da soberania nacional. Contudo, em qualquer dessas hipóteses é necessário o retorno imediato após cessarem os riscos (BULOS, 2009, p. 1448). O $\S 6^{\circ}$ torna nulos e extintos os atos que tenham por objeto a ocupação, o dominio e a posse das terras referentes ao Art. 231, conforme a lei complementar (BULOS, 2009, p. 1448). O $\S 7^{\circ}$ apenas refere-se aos $\S \S 3^{\circ}$ e $4^{\circ}$ do Art. 174 da $C F$ de 1998 por não serem aplicáveis em caso de terras indígenas. O Art. 232 trata da legitimidade judicial dos indígenas e da necessidade de intervenção do Ministério Público quando a questão indígena for objeto de ação judicial (BRASIL,1988).

Em âmbito internacional, é preciso destacar que o Brasil é signatário da Convenção n. 169 da Organização Internacional do Trabalho (OIT), relativa aos povos indígenas e tribais. Tal documento trata da conservação de identidades e peculiaridades integrantes da riqueza e diversidade culturais indígenas. Assim, o Art. $4^{\circ}$, 1, da citada Convenção diz: Deverão ser adotadas as medidas especiais que sejam necessárias para salvaguardar as pessoas, as instituições, os bens, as culturas e o meio ambiente dos povos interessados (ORGANIZAÇÃO INTERNACIONAL DO TRABALHO, 2013). ${ }^{16}$

\section{Perspectiva indígena no Brasil: considerações históricas e atuais}

Nesta seção, serão invocadas algumas perspectivas que se consideram importantes para a temática desenvolvida. Assim, não se pretende exaurir o tema indígena, mas trazer dados para problematizar essa questão, com aspectos sociais, culturais, econômicos e políticos. Atualmente, tais dados refletem a disputa de terras e a perda de espaço na cultura brasileira. Quando os portugueses chegaram às

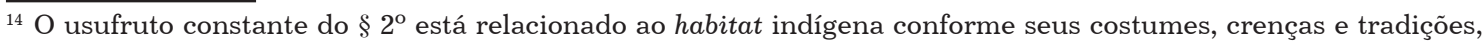
justamente para que tenham interação com a natureza e autonomia interna, sem interferências externas a fim de viverem em paz com o meio ambiente que os circunda, possibilitando-lhes, no mínimo, a manutenção de sua cultura (BULOS, 2009, p. 1447).

${ }^{15}$ Esse parágrafo regula o aproveitamento dos recursos hídricos, a pesquisa e a lavra das riquezas minerais em terras indígenas com expressa autorização do Congresso Nacional. Essa norma é controversa, justamente pela exploração de terras habitadas e destinadas aos índios; contudo, a proteção em relação a essa exploração encontra-se na atenção específica que o legislador pátrio deve ter (BULOS, 2009, p. 1447-1448).

16 Destaca-se que, segundo Antunes (2013, p. 1352), foi remetida ao Congresso Nacional a mensagem 367 de 16 de julho de 1991 - referente à Convenção - que ainda não foi aprovada pelo Legislativo.
} 
terras do futuro Brasil, existiam por volta de dois milhões de índios (SILVA, 1990, p. 64-65). Atualmente, segundo o Instituto Brasileiro de Geografia e Estatística (IBGE) (2013b), a população indígena é de 896,9 mil, distribuídos em 305 etnias, totalizando 274 idiomas. Isso demonstra que o desenvolvimento constitucional ainda não revela a realidade da sociedade brasileira.

O termo índio fora utilizado pelos grupos liderados por Cristovão Colombo em 1492, para designar os habitantes das terras ameríndias, pois os primeiros tinham a ideia equivocada de estar pisando em terras das Índias. Data-se, a partir de então, o processo de colonização das Américas e a consequente problemática indígena que, tendo passados cinco séculos, ainda mostra reflexos. Conforme Carneiro da Cunha (2012, p. 8), "Ao chegarem às costas brasileiras, os navegadores pensaram que haviam atingido o paraíso terreal: uma região de eterna primavera, onde se vivia comumente por mais de cem anos em perpétua inocência."

De acordo com a historiografia trazida pela Fundação Nacional do Índio (2013), os portugueses, ao chegarem no litoral brasileiro, iniciaram um processo de migração que se alongou até o início do século XX. Dessa forma, ocuparam-se as terras que, até então, eram indígenas.

Diante do exposto, identifica-se o artifício que começa a colonização do Brasil e o choque interétnico que, como se percebeu ao longo da história, acabou por privilegiar uma cultura dominante; nesse caso, a europeia. Ademais, é possível falar em uma relação de perda de identidade por parte dos índios que aqui habitavam, pois os costumes e as normas dos europeus foram impostos de forma coercitiva à sociedade indígena. Carneiro da Cunha (2012) ressalta isso, afirmando que os povos indígenas desapareceram em decorrência do que se denomina, "[...] na forma de um eufemismo envergonhado, o encontro de sociedades do Antigo e do Novo mundo." (CARNEIRO DA CUNHA, 2012, p. 14).

Já está mais do que consolidado que a história dos índios brasileiros não está datada a partir de 22 de abril de 1500, com a chegada das caravelas portuguesas ao solo da antiga ilha de Vera Cruz. Fato esse que é elucidado pelos próprios indígenas, como afirmou o índio Marsal Tupã-i no encontro dos Povos Indígenas com o Papa João Paulo II, em junho de 1980: "Nossas terras são invadidas, nossas terras são tornadas, os nossos territórios são inválidos. Dizem que o Brasil foi descoberto. O Brasil não foi descoberto, não! O Brasil foi invadido e tomado dos indígenas do Brasil. Essa é a verdadeira história." (MARÇAL TUPÃ-I, 2001, p. 99).

O depoimento supracitado converge com a afirmação de Galeano (2012, p. 17), o qual afirma que a América Latina, ao longo do tempo, foi se especializando "em perder", desde a chegada do Renascimento europeu pelos mares com a sua extrema vontade de explorar novas terras virgens. Entende-se perda não apenas no sentido de matéria-prima, como o pau-brasil, mas também perda de cultura, de identidade, perda de vida, "[...] da terra, dos frutos e suas profundezas ricas em minerais, dos homens e sua capacidade de trabalho [...], dos recursos naturais e humanos." (GALEANO, 2012, p. 18). O autor vai além: afirma que o ímpeto explorador da Espanha e 
de Portugal, somado à fé cristã, colaborou para a usurpação da cultura e dos valores indígenas na América Latina como um todo, em especial no Brasil. Essa perspectiva corrobora a de Carneiro da Cunha (2012), a qual afirma que a ambição e a ganância dos colonizadores, somadas às formas culturais impostas pelo capitalismo mercantil, foram fundamentais para o assustador déficit na população indígena no Brasil, ao longo desses cinco séculos. Outros fatores também contribuíram para tamanha mortalidade indígena, como epidemias, conflitos diretos, escravidão, fome, desorganização social, entre outros. Conforme aborda a história formulada pela Fundação Nacional do índio (2013):

O processo de colonização levou à extinção muitas sociedades indígenas que viviam no território dominado, seja pela ação das armas, seja em decorrência do contágio por doenças trazidas dos países distantes, ou, ainda, pela aplicação de políticas visando à "assimilação" dos índios à nova sociedade implantada, com forte influência europeia.

Esse processo de "perda cultural" torna-se manifesto quando os dados da Fundação Nacional do Índio apontam que cerca de 1 a 10 milhões de indígenas habitavam as terras ameríndias naquele período. Segundo o IBGE (2013a), a população indígena hoje no Brasil é de 817,963 mil índios, o que equivale, em média, a 0,4\% da população brasileira, que, no último censo do IBGE de 2010, era de mais de 190,755 milhões. Para tanto, elucidam-se tais números, apresentando a Tabela 1, que permitirá formular uma breve explicação para problematizar a disputa de terra em que os índios estão envolvidos, na contemporaneidade.

Tabela 1 - Disputa de terra em que os índios estão envolvidos, na contemporaneidade

\begin{tabular}{lrrr}
\hline & 1991 & $\mathbf{2 0 0 0}$ & $\mathbf{2 0 1 0}$ \\
\hline Total (1) & 146.815 .790 & 169.872 .856 & 190.755 .799 \\
Não indígena & 145.986 .780 & 167.932 .053 & 189.931 .228 \\
Indígena & $\underline{294.131}$ & $\underline{734.127}$ & $\underline{817.963}$ \\
\hline Urbana (1) & 110.996 .829 & 137.925 .238 & 160.925 .792 \\
Não indígena & 110.494 .732 & 136.620 .255 & 160.605 .299 \\
Indígena & $\underline{71.026}$ & $\underline{383.298}$ & $\underline{315.180}$ \\
Rural (1) & 35.818 .961 & 31.947 .618 & 29.830 .007 \\
Não indígena & 35.492 .049 & 31.311 .718 & 29.325 .929 \\
Indígena & $\underline{223.105}$ & $\underline{350.829}$ & $\underline{502.783}$ \\
\hline
\end{tabular}

Fonte: IBGE (2013a).

Nota: Considerou-se como população residente não indígena as categorias de um a quatro do quesito cor ou raça.

Percebe-se, com base na Tabela 1, que no período correspondente, entre 1991 e 2010, a população indígena aumentou consideravelmente em sua totalidade. Todavia, não se pode ter a ilusão, causada pelos dados quantitativos, de que a situação dos índios no Brasil está em posição de melhora. Pelo contrário, mesmo com a Constituição Federal de 1988, em seu capítulo VIII, Art. 231, § 2ª , assegurando ao povo indígena 
o direito à terra, no qual está dito que "[...] as terras tradicionalmente ocupadas pelos índios destinam-se a sua posse permanente, cabendo-lhes o usufruto exclusivo das riquezas do solo, dos rios e dos lagos nelas existentes" (BRASIL, 1988), muitos conflitos envolvendo latifundiários e índios são centrais no debate sobre a problemática que envolve o,s índios e a demarcação de terras no país. Noticiários mostram constantemente a morte de índios que se envolvem em constantes, violentos e sangrentos embates com fazendeiros. Considerando o que foi assinalado, o histórico da população indígena e a "perda cultural" causada pelo choque intercultural com a colonização europeia no Brasil, principalmente a portuguesa, faz-se necessário esclarecer os fatos atuais, os quais emergem como práticas que ferem a Constituição Federal de 1988, no que diz respeito à questão indígena e ao direito à terra.

\section{As violações à memória constitucional}

Ao compararem-se as Constituições brasileiras anteriores à de 1988, constata-se que as normas que diziam respeito aos povos indígenas, basicamente, restringiram-se às suas terras, no sentido de sua delimitação e utilização. De fato, tais terras sempre foram motivos de disputas, as quais envolvem diversos interesses de diferentes setores econômicos brasileiros. A CF de 1988 insere uma nova perspectiva em relação aos povos indígenas, estabelecendo o que deveria ter sido consolidado desde a primeira Constituição; pelo menos, a primeira republicana. A memória do que os povos indígenas passaram, e ainda passam, veio à tona na CF de 1988. Porém, os fatos cotidianos não demonstram o respeito exigido pela Carta Magna. ${ }^{17}$

Tal desconsideração ao Capítulo VIII da Constituição Federal é trazida em vários debates entre organizações sociais, movimentos sociais e profissionais que trabalham na defesa do direito à terra para os povos indígenas brasileiros. Em manifesto assinado por diversos profissionais, entre eles médicos, sociólogos e antropólogos, disponível na revista virtual Brasil de Fato, esse problema é questionado da seguinte maneira:

De que tratam e para quem servem os tais caminhos unilaterais de "progresso" e "desenvolvimento" de uma nação, se eles não são acompanhados, passo a passo, por seu desenvolvimento humano e do respeito à sua Constituição? (ANTROPÓLOGOS..., 2013).

É possível perceber, frente a isso, que existe um rígido embate envolvendo principalmente três atores: os índios, os donos de terra (latifundiários) e o Governo brasileiro. Pode-se afirmar, em decorrência dessa relação conflituosa, que os índios são os que mais perdem nesse "jogo de interesses". Exemplo disso é, ainda, a inconclu-

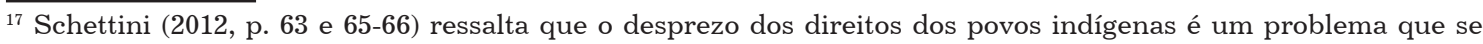
estende pelo continente latino-americano, mesmo com a previsão de direitos e garantias a tais povos. Os povos indígenas ganham maior evidência e suporte jurídico ao terem seus direitos reconhecidos e jurisdicionados, também, pelo âmbito de Direito Internacional dos Direitos Humanos.
} 
são da demarcação das terras indígenas e o desalojamento das aldeias ${ }^{18}$ para a construção da usina de Belo Monte, ${ }^{19}$ localizada no Estado do Pará, que, no atual processo de elaboração, está causando grandes impactos para os que vivem na região.

Outro exemplo, não menos importante são as disputas entre os latifundiários da região do Oeste brasileiro e os índios Guarani-Kaiowá. Pode-se citar o caso de reivindicação de terra da comunidade Pyelito Kue e Kaiowá, situada na bacia de Iguatemipeguá (Mato Grosso do Sul). A área do litígio coincide com a área de estudo das terras de ocupação tradicional da comunidade indígena, que foi retirada na década de 1920, por meio de ação da política indigenista, e passa a ser reocupada desde novembro de 2011. Mas a reocupação limita-se a dois hectares, em contraste com os 762 hectares do antigo território, a atual fazenda Cambará. O atual proprietário mantém sua posse por meio de diversos subterfúgios legais e ilegais, encontrando-se, assim, a comunidade indígena em situação de vulnerabilidade (CARTA..., 2012). ${ }^{20}$ Destaca-se que o território é elemento constituinte do modus vivendi da etnia Kaiowá (LIMBERTI, 2009, p. 171). O Ministério Público, imbuído da missão de proteger e representar os direitos indígenas, questionou a propriedade do fazendeiro. Um dos argumentos foi a utilização da influência política, ao expropriar a área indígena para se beneficiar com o reconhecimento da propriedade. Tais terras foram da comunidade indígena da aldeia Pyelito. O Juiz federal de Naviraí decidiu favoravelmente ao fazendeiro, ao fundamentar sua decisão em preceitos possessórios do Código Civil e do Processo Civil (SILVA; SOUZA; SOUSA, 2013, p. 50-51).

Esses conflitos, conforme dito, também possuem uma parcela das instâncias governamentais, no nível municipal, estadual ou federal. O Governo brasileiro, muitas vezes, parece se isentar dessas questões. Em vez de fazer cumprir o Texto Constitucional, acaba por deixar as reivindicações indígenas à mercê dos grandes proprietários de terra. Entenda-se por Governo todas as suas partes, como Legislativo, Executivo e Judiciário, além dos estados e municípios.

\footnotetext{
${ }^{18}$ Segundo a Constituição Federal de 1988, é possível defender a inconstitucionalidade da remoção das aldeias indígenas para a construção de Belo Monte. São destacáveis os seguintes dispositivos: Art. 231 da CF nos seguintes $\S \S$ $\S 2^{\circ}$ declara que as terras tradicionalmente ocupadas pelos índios se destinam à sua posse permanente. As terras, referentes ao $\S 2^{\circ}$, estão definidas no $\S 1^{\circ}$ do mesmo artigo. Para reforçar o argumento da inamobilidade dos índios, encontra-se no $\S 4^{\circ}$ que declara tais terras como inalienáveis e indisponíveis e, os direitos sobre estas, imprescritíveis. Tais características fornecem a solução para Belo Monte, porém, para reforçar a inamobilidade, invoca-se o $\S 5^{\circ}$ que dá uma impressão de que os povos indígenas poderiam ser realocados, excepcionalmente, em outras terras em caso de catástrofes ou epidemias que ponham em risco a população, ou no interesse da soberania do país, é garantido, em qualquer das hipóteses, o retorno imediato logo que cesse o risco. Então, mesmo em casos excepcionais, o retorno é garantido imediatamente que cessar o motivo do deslocamento. Por conseguinte, o motivo de transferir os índios que se localizam no espaço em que a usina de Belo Monte se instalar não tem fundamento constitucional: pela indisponibilidade da terra por parte dos índios; a instalação da usina não tem caráter temporário como exige o $\S 5^{\circ}$; a indisponibilidade da terra tradicionalmente ocupada pelos índios e a obrigação de retorno daqueles que foram realocados às terras originais constituem garantias fundamentais de tais povos. Está-se diante de um direito impossível de ser alterado por emenda constitucional (Art. 60, § 4º IV, da CF).

19 A usina de Belo Monte está localizada no Rio Xingu, no Estado do Pará. Segundo o Governo federal, a usina vai produzir energia suficiente para abastecer $40 \%$ do consumo residencial de todo o Brasil (PORTAL BRASIL, 2013).

20 Carta da comunidade Guarani-Kaiowá sobre a sua situação.
} 
Por conseguinte, violações no campo da saúde e da educação também são latentes nesse cenário. Segundo informações do Observatório Indígena (2013), as principais seriam:

[...] negação de atendimento pela FUNASA a índios desaldeados, cobrança de valores decorrentes da implantação do sistema de saneamento em terras indígenas, falta de saneamento básico, ausência de concurso público específico para professores indígenas, atraso no pagamento dos professores indígenas, falta de recursos para a manutenção das escolas indígenas, falta de pessoal para exercer as funções de merendeiro/a e zelador/a nas escolas indígenas, descumprimento da Lei Orçamentária Anual Estadual.

Nesse caso, em especifico, Karl Marx parecia ter razão em afirmar que o Estado funcionaria como uma ferramenta de manutenção da classe dominante. Aqui, essa classe dominante compreende os grandes donos de terra, especialmente o agronegócio que, a título de hipótese, é um dos maiores causadores dos problemas envolvendo a regularização fundiária no Brasil. Basta identificar os processos de disputa, plantio com agrotóxicos, desmatamentos, entre outros exemplos da prática econômica latifundiária que, para além dessas questões, possui grande influência no jogo político do país. É possível perceber tais considerações a partir da cobrança que as mídias alternativas fazem em relação a esses interesses empresariais e governamentais que, em certa medida, parecem não considerar a Carta Magna de 1988. No mesmo manifesto da Revista Brasil de Fato, os profissionais que ali assinam levantam a seguinte questão:

[...] nem mesmo a ideologia empresarial pode ser sobreposta à Constituição Federal do país ou justificar sua brutal violação. Seu fim primordial é garantir fundamentalmente o bem-estar de sua população como um todo, o que inclui todos os segmentos diferenciados do país e as gerações vindouras. (ANTROPÓLOGOS..., 2013).

Percebe-se, diante disso, o embate que permeia a regularização fundiária no Brasil atualmente. Mesmo com proteção ao índio, tido como cidadão com direito à terra, conforme a $\mathrm{CF}$, os interesses econômicos dos grandes latifundiários acabam por sobrepor essa condição imposta pela lei. Ademais, esses fatores contribuem para a emergência de graves conflitos, tanto físicos quanto institucionais, que levam a violações de direitos fundamentais, a violências (como a morte do índio terena Oziel Gabriel) (MANIFESTANTES..., 2013) no campo e à lentidão na demarcação das terras indígenas (em evidente violação à Carta Magna). Isso ocorre, em grande medida, em razão do alto do lobby político que os produtores rurais exercem no campo da política brasileira, conforme alerta o texto da Carta Capital:

O outro forte fator que agrava a crise no Mato Grosso do Sul é o grande poder político da elite local, particularmente acentuado na conjuntura atual, em que o agronegócio se tornou um dos pilares de um modelo econômico baseado, em grande parte, na exportação de commodities primárias [...] O poder econômico e político dessa elite local, fortemente associada ao capital transnacional que financia o agronegócio, protelou ao máximo o processo 
de demarcação das terras indígenas na região. Desde que o movimento indígena Aty Guasu passou a organizar ocupações de terra como estratégia para pressionar o Estado brasileiro a agir na região, em meados dos anos 1980, a Fundação Nacional do Índio sempre agiu de forma pontual, sem buscar uma solução estrutural para os conflitos. Uma determinada área era ocupada, e somente ali se iniciava um processo de identificação e delimitação. (O DESAFIO..., 2012).

Esses depoimentos mostram como há uma prática de violação da $\mathrm{CF}$, pois a cultura indígena, os seus costumes e o direito à terra são desrespeitados em prol dos grandes interesses latifundiários no Brasil. Além disso, evidenciam uma inércia por parte das instituições governamentais, quando não fazem cumprir a lei presente na CF de 1988.

\section{Conclusão}

A história constitucional brasileira possibilita a análise de desrespeito aos povos indígenas; porém, a Constituição de 1988 estabelece outra condição ao índio. No entanto, em decorrência dos fatos abordados até aqui, pode-se entender que o período de colonização no Brasil já está encerrado há quase dois séculos. todavia, as práticas colonizadoras, como discriminação para com os índios, desvalorização dos padrões culturais, desrespeito ao seu direito à terra e à cultura, entre outros, ainda se fazem latentes na realidade brasileira. Um fato que elucida tal afirmação são as constantes "violações" ao Título VIII e ao Capítulo VIII da Constituição Federal de 1988, implicando, dessa maneira, constantes dramas para a população indígena, que, em frente a esse jogo de forças e interesses, acaba por sair em desvantagem.

Violações em nível de saúde, educação, meio ambiente, entre outras, também estão presentes no seio dessa relação desigual e infratora. Percebe-se que os interesses dos grandes latifundiários e os do agronegócio não consideram a Carta Magna, a qual considera o índio como cidadão de direito, principalmente à terra e à cultura. Observa-se, a partir do exposto, que lucrar acima dos pressupostos presentes da $\mathrm{CF}$ e às custas de uma tradição histórico-colonizadora impera no Brasil de forma latente.

Disputas por terras atravessam a linha histórica do Brasil Colonial e pós-colonial. Todavia, diante do desenvolvimento e do crescimento econômicos que perpassaram o país, essa lógica conflituosa não acompanhou a "maturidade" da nação. Vive-se, ainda, uma mentalidade colonial como as dos séculos XIX e XX, em que a memória e a cultura da população indígena são negligenciadas em prol de interesses econômicos dos grupos que lideram determinado contexto social, político e cultural. Nesse caso, no Brasil, os interesses dos representantes do agronegócio e outros, que não os indígenas, possuem mais força que as normas constitucionais. Embora a índole constitucional esteja sendo contrariada constantemente, o Estado brasileiro não tem interesse ou força para concretizar as normas constitucionais referentes à questão indígena. 


\section{Referências}

ANTROPÓLOGOS brasileiros divulgam manifesto sobre demarcação de terras indígenas. Brasil de Fato, São Paulo, 04 jun. 2013. Nacional. Disponível em: <http:// www.brasildefato.com.br/node/13110 >. Acesso em: 07 jul. 2013.

ANTUNES, Paulo de Bessa. Direito ambiental. 15. ed. São Paulo: Atlas, 2013.

BULOS, Uadi Lammêgo. Curso de direito constitucional. 4. ed. São Paulo: Saraiva, 2009.

CARTA da comunidade Guarani-Kaiowá de Pyelito Kue/Mbarakay-Iguatemi-MS para o Governo e Justiça do Brasil. Comissão Pastoral da Terra, Goiânia, 23 out. 2012. Disponível em: <http://www.cptnacional.org.br/index.php/noticias/13-geral/1293-carta-da-comunidade-guarani-kaiowa-de-pyelito-kue-mbarakay-iguatemi-ms-para-o-governo-e-justica-do-brasil>. Acesso em: 18 ago. 2013.

CARNEIRO DA CUNHA, Manuela. Índios no Brasil: história, direitos e cidadania. São Paulo: Claro Enigma, 2012.

CONFERENCIA NACIONAL DOS BISPOS DO BRASIL. Por uma terra sem males: fraternidade e povos indígenas: manual. São Paulo: Salesiana, 2001.

BRASIL. Constituição da República dos Estados Unidos do Brasil de 1891. 1891. Disponível em: <http://www.planalto.gov.br/ccivil_03/Constituicao/Constituicao91. htm >. Acesso em: 01 jan. 2013.

BRASIL. Constituição Política do Império do Brasil de 1924. 1924. Disponível em: $<$ http://www.planalto.gov.br/ccivil_03/Constituicao/Constituicao24.htm>. Acesso em: 01 jan. 2013.

BRASIL. Constituição da República dos Estados Unidos do Brasil de 1934. 1934. Disponível em: < http://www.planalto.gov.br/ccivil_03/Constituicao/Constituicao34. htm >. Acesso em: 03 jan. 2013.

BRASIL. Constituição dos Estados Unidos do Brasil de 1937. 1937. Disponível em: $<$ http://www.planalto.gov.br/ccivil_03/Constituicao/Constituicao37.htm>. Acesso em: 03 jan. 2013.

BRASIL. Constituição dos Estados Unidos do Brasil de 1946. 1946. Disponível em: $<$ http://www.planalto.gov.br/ccivil_03/Constituicao/Constituicao46.htm>. Acesso em: 03 jan. 2013.

BRASIL. Constituição da República Federativa do Brasil de 1967. 1967. Disponível em: <http://www.planalto.gov.br/ccivil_03/Constituicao/Constituicao67.htm>. Acesso em: 04 jan. 2013. 
BRASIL. Constituição (1988). Emenda Constitucional n. 1, de 17 de outubro de 1969. Edita o novo texto da Constituição Federal de 24 de janeiro de 1967. Diário Oficial da União, Brasília, DF, 30 out. 1969. Disponível em: < http://www.planalto. gov.br/ccivil_03/Constituicao/Emendas/Emc_anterior1988/emc01-69.htm>. Acesso em: 04 jan. 2013 .

BRASIL. Constituição. República Federativa do Brasil de 1988. Brasília, DF: Senado Federal, 1988.Disponível em: < http://www.senado.gov.br/legislacao/const/ con1988/CON1988_29.03.2012/CON1988.pdf>. Acesso em: 05 jan. 2013.

FUNDAÇÃO NACIONAL DO ÍNDIO. A origem dos Povos Americanos. Disponível em: <http://www.funai.gov.br/>. Acesso em: 07 jul. 2013.

FUNDAÇÃO NACIONAL DO ÍNDIO. Há 500 anos. Disponível em: < http://www. funai.gov.br/>. Acesso em: 07 jul. 2013.

GADAMER, Hans-Georg. Verdade e Método I. Tradução Flávio Paulo Meurer. 9. ed. Petrópolis: Vozes, 2008.

GALEANO, Eduardo. As Veias Abertas da América Latina. Porto Alegre: L\&PM, 2012.

HÄBERLE, Peter. Die Verfassung des Pluralismus. Studien zur Verfassngstheorie der offenen Gesellschaft. Königstein, TS: Athenäum, 1980.

HESPANHA, António Manuel. O direito e a história. Os caminhos de uma história renovada das realidades jurídicas. Revista de Direito e de Estudos Sociais, Coimbra, ano 17, n. 2,3 e 4, p. 7-68, 1971.

IBGE. Censo Demográfico: 1991/2010. Disponível em: <//indigenas.ibge.gov.br/graficos-e-tabelas-2>. Acesso em: 07 jul. 2013a.

IBGE. Censo 2010: população indígena é de 896,9 mil, tem 305 etnias e fala 274 idiomas. Disponível em: < http://www.ibge.gov.br/home/presidencia/noticias/noticia_visualiza.php?id_noticia=2194\&id_pagina=1>. Acesso em: 13 jan. 2013b.

KRIELE, Martin. Einführung in die Staatslehre. Die geschichtlichen Legitimitätsgrundlagen des demokratischen Verfassungsstaates. 4. Aufl. Opladen: Westdeutscher Verlag, 1990.

LIMBERTI, Rita de Cássia Pacheco. O índio Guarani-Kaiowá da reserva indígena de Dourados, Mato Grosso do Sul, Brasil: Um olhar semiótico. Revista Polifonia, Cuiabá, n. 18, p. 169-184, 2009. Disponível em: < http://cpd1.ufmt.br/meel/arquivos/ artigos/332.pdf $>$. Acesso em: 18 ago. 2013. 
MANIFESTANTES fazem marcha em protesto contra norte de índio em MS. G1, 04 jun. 2013. Disponível em: < http://g1.globo.com/mato-grosso-do-sul/noticia/2013/06/manifestantes-fazem-marcha-em-protesto-morte-de-indio-em-ms. html >. Acesso em: 10 jul. 2013.

MARÇAL TUPÃ-I. Cimi/CNBB, 1980. Povos da esperança construindo outros 500. In: Conferência Nacional dos Bispos do Brasil. Por uma terra sem males: fraternidade e povos indígenas. São Paulo: Editora Salesiana, 2001.

OBSERVATÓRIO INDÍGENA. Disponível em: < http://www.observatorioindigena. ufc.br/oktiva.net/1983/secao/12973>. Acesso em 16 jul. 2013.

O DESAFIO da paz. Carta Capital, 14 fev. 2012. História. Disponível em: < http:// www.brasildefato.com.br/node/13110>. Acesso em: 07 jul. 2013.

ORGANIZAÇÃO INTERNACIONAL DO TRABALHO. Sobre Povos Indígenas e Tribais. Convenção n. 169. Disponível em: <www.oit.org.br/node/513>. Acesso em: 01 set. 2013.

PORTAL BRASIL. Disponível em: < http://www.brasil.gov.br/sobre/economia/energia/obras-e-projetos/belo-monte/print>. Acesso em: 08 jul. 2013.

SCHETTINI, Andrea. Por um novo paradigma de proteção dos direitos dos povos indígenas: uma análise crítica dos parâmetros estabelecidos pela Corte Interamericana de Direitos Humanos. SUR - Revista Internacional de Direitos Humanos, São Paulo, v. 1, n. 1, p. 63-85, jan. 2004.

SILVA, Francisco Carlos Teixeira da. Conquista e colonização da América portuguesa: o Brasil colônia - 1500/1750. In: Maria Yeldda Linhares (Org.). História geral do Brasil. 9. ed. Rio de Janeiro: Elsevier, 1990.

SILVA, Maria Graciele Silveira Santos; SOUZA, Laryssa Graziella Rocha de; SOUSA, Maria Sueli Rodrigues de. Comunidade Marambaia e índios Kaiowá-Guarani: discussão acerca de minorias étnicas e sua integridade cultural com base em decisões de demarcação dos territórios. Direito \& Justiça. Revista da Faculdade de Direito da PUCRS, Porto Alegre, v. 1, n. 1, p. 48-54, 2013.

TOURAINE, Alain. O que é a democracia? Tradução Guilherme João de Freitas Teixeira. 2. ed. Petrópolis: Vozes, 1996.

VORLÄNDER, Hans. Die Verfassung. Idee und Geschichte. 3. Aufl. München: Beck, 2009.

Data da submissão: 24 de outubro de 2013 Avaliado em: 13 de maio de 2014 (Avaliador A) Avaliado em: 28 de maio de 2014 (Avaliador B) Aceito em: 27 de novembro de 2014 
